腸などの凍結標本を作のた。これらの標本をストリッ ピング法により microradioautogram を作製した。

スライドにみら机るのは小腸で左が対照, 右が加㾏 したものである. 細胞の核内への Thymidine の取込 タはあまり美がない。

次のスライドは腫瘍組織であるが左が対照, 右が加 任したものである。酸素加圧をおこなった方が取り込 みが多いこれれり腫瘍組織で仿酸秦加区により, DNA 合成が蓠まっていると考えられる。即ち小腸では代謝 があまり変わらないのに腫愓組織では䯩まっている。

酸素分圧が非常に唐い状態では組織代謝は抑制され るということは一般にみとめられている。従って高圧 酸素下では正常組織の酸素分圧は上犁し代謝は抑制さ れ放射線感受性が低下゙するのに友し，腫淔組織におい ては元来 Anoxic な状態にあり酸素加代によっても酸 素分性漂端に上景せず，従って Anoxic な状態が改 善され代謝が高まり，この高まった状態で放射線感受 性が堌すものと轺えられる。

演題 24

\section{高酸素分圧と放射線感 受性（2）}

高圧酸素下での腫瘍細胞に 対与る放射線感受性の検討

\begin{tabular}{|c|c|c|}
\hline 東京大学 & 㸝部外科 & 古田昭一・佐藤富蔵 \\
\hline " & 中央手術部 & 呉 大順 - 高木忠信 \\
\hline " & 放射線科 & 亘理 勉 \\
\hline " & 麻 酔 科 & 山村秀夫 \\
\hline " & 保健学科 & 山本俊一・長谷川斐子 \\
\hline "I & 潜 学 部 & 日野茂男 \\
\hline
\end{tabular}

実験腫瘍を用い，高酸素分压下の放射線感受性の問 題を 3 H-Thymidine の転入率より検封して次の結果 在得た。

1) in vitro での $\mathrm{AH} 130$, in vivo での Erhlich 腫 陽ともに，腫瘍細胞の DNA への $3 \mathrm{H}$-thymidine の 転入率は，嗃酸素分圧下では 120１30\%に增加した が，空気加王では增加しなからた。

2）放射線増感性に関しては，in vitroの実験では 放射線 $4000 \mathrm{R}$ で詨照は $79 \%$ あるるのに比し，滈酸素 分圧下，絶対 4 気压下で $60 \%$ と僅かに低下寸るに過ぎ ないが，in vivo では $1000 \mathrm{R}$ 监独照射で $50 \%$ と減少 した．絶対 2 気过，4氛王と加压するに従い，40\%， $20 \%$ と著しく低下した。

放射線照射㭙の酸素効果は in vitro よりも in vivo
でより明膫に現われることは興味ある事実である。

追加

\section{演 題 23}

高気圧酸素環境の吉田肉腫細 胞世代時間におよぼす影響

名古屋大学 橋本外科

\section{長田卓二・服部竜夫・森澄 浅野多一・武市暸・岡田達郎 紀藤毅・榊原欣作}

我々は腹水型吉田肉腫移植吞童ラッテにたいして高 気压酸素環境絶対気压 30 分 1 回および 3 回群に $3 \mathrm{H}$ Thymidine $10 \mu \mathrm{C}$ 投与し，担癌体への高全压酸素 環境の影響を世代時間を視察することによって追求し た.

すなわち世代時間は対照群では 17.4 時間, OHP 1回 群では 21.4 時間, OHP 3 问群では 22.8 時間となり対

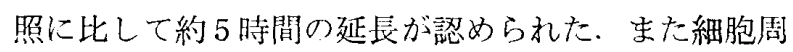
期は $\mathrm{G}_{2}$ 期が対照群 3 時閒にたいして OHP 1 回群で は 4.2 時間, OHP 3 回群では 5.9 時となり対照群に比 してほぼ 2 倍の延長が観察された. $\mathrm{S}$ 期， $\mathrm{G}_{1}$ 期，M期 の有意の延長，短縮は視察されなかった.

演題 24

名古屋大学 橋本外科

\section{浅野多一・服部竜夫・森澄 武市 暸・岡田達郎・長田卓二 紀 藤毅}

OHP の細胞レベルにおける影響を解析する目的で HeLa と FL 細胞を用い増殖におよぼす影響を検討し t.

実験方法：単層培養 YLE, LH 培養液( $10 \%$ 仔牛血 清)学使用. OHP (3 atm, abs)，OAP (大気庄, 純酸 素) AAP (大気圧, 空気) の 3 群を観察の対象とし, $\mathrm{AAP}$ て䘮対照群とし， OHP， OAP 処置時間は 1, 6, 12,24 時間の 4 群とし，24 時間毎に6 日間細胞数を測 定. 細胞数測定には核数計算と Viable cell count を 用いた。

実験結果 : HeLa，FL 共実験群では lag Phase の延 長を認め Maximum size も低く，処置時間の延長は これをつよめる．24時間処置で OAP 群は増殖するが OHP 群は增殖がみられない. HeLa と FL との間に 多少の相異があるので，更にViable cell count を行 ならと, HeLa 注終始対照群に比して dead cell の高 蔀孛示すのに対して FL は 3 日後より順次下降を示 